\title{
Szymon Grygiel
}

\section{Ciało i świętość. Przypadek XIX-wiecznych świętych starców rosyjskich}

nspiracją do podjęcia niniejszego tematu jest fragment powieści Bracia Karamazow Fiodora Dostojewskiego. Rzecz dzieje się w XIX-wiecznym rosyjskim monasterze. Umiera czcigodny starzec Zosima. Gromadzący się przy trumnie zmarłego pielgrzymi oraz mnisi pełni napięcia oczekują na cud. Spotyka ich jednak rozczarowanie. Ciało zmarłego zaczyna bowiem wydawać związany z gniciem nieprzyjemny zapach, odczytany przez świadków jako znak woli bożej przeczący świętości zmarłego. Argument ojca Józefa, przekonującego, że „prawosławie nie uważa bynajmniej za dogmat, iż zwłoki sprawiedliwych nie mogą ulegać rozkładowi" (Dostojewski, 1984, s. 393), nie zyskuje przychylności wśród zgromadzonych w celi starca, przypisujących nieboszczykowi negatywne cechy.

Zdumiewające, że niewiele ponad dwadzieścia lat po wydaniu Braci Karamazow sytuacja podobna do przedstawionej przez Dostojewskiego miała miejsce tuż przed kanonizacją starca Serafina z Sarowa. Świadczy o tym artykuł zamieszczony w "Gazecie Polskiej" z 7 lipca 1903 roku, cytujący stanowisko metropolity Petersburga Antoniego w sprawie szczątków św. Serafina. Przesycony atmosferą skandalu spór, toczący się w Rosji na szerokim forum społecznym, dotyczył wpływu stanu zachowania relikwii zmarłego siedemdziesiąt lat wcześniej sarowskiego starca na słuszność zaliczenia go do grona świętych?.

Dostrzeżenie podobieństwa pomiędzy obrazem literackim a historycznym sprawiło, że postanowiłem zastanowić się nad środkami służącymi sakralizacji oraz desakralizacji

\footnotetext{
${ }^{1}$ Zob. „Gazeta Polska” 07.07.1903, 183, s. 2.
} 
ciał XIX-wiecznych rosyjskich starców w dotyczących ich tekstach ${ }^{2}$. Moim celem nie jest polemika z uznawanymi w prawosławiu wyznacznikami bycia świętym (zob. Przybył, 2006, s. 204 oraz Charkiewicz, 2010a, ss. 109-122), lecz przybliżenie związanych z cielesnością przykładów służących budowaniu lub negowaniu obrazu świętości. Zamierzam rozważyć trzy stany ciała świętego: za życia, tuż po śmierci oraz w postaci relikwii.

W XIX wieku odrodziła się w Rosji instytucja starczestwa, odwołująca się do tradycji nauk Ojców Pustyni oraz hezychazmu (gr. hezychia, czyli spokój duszy; zob. Przybył, 2006, s. 95) - kontemplacyjnego nurtu, który na średniowieczną Ruś przedostał się ze wspólnoty monastycznej na górze Athos (zob. Ochał, 1994, s. 254). Słowo starzec w tym przypadku oznacza osobę niekoniecznie w mocno zaawansowanym wieku, wskazuje natomiast, jak pisze Dorota Piekarska-Winkler (2003, s. 123), na "starszeństwo duchowe". Ów rozkwit nastąpił głównie za sprawą mołdawskiego starca Paisjusza Wieliczkowskiego, autora wydanego w 1793 roku przekładu Filokalii (tekstu dotyczącego praktykowanej przez starców Modlitwy Jezusowej) na język cerkiewno-słowiański. Starzec - przewodnik duchowy zamieszkujący zwykle położoną niedaleko monasteru pustelnię - był wybierany spośród zakonników. Najczęściej nie posiadał święceń kapłańskich. Był schimnikiem - mnichem żyjącym według ścisłej, pokutniczej reguły (Piekarska-Winkler, 2003, ss. 123-125; Ochał, 1994, s. 256).

Dwa najważniejsze ośrodki działalności rosyjskich starców w XIX wieku to Pustelnia Sarowska (z najsłynniejszym starcem, św. Serafinem, zmarłym w 1833 roku) oraz Pustelnia Optyńska, położona niedaleko Kozielska. Początki starczestwa w Optynie wiążą się z wizytą biskupa Kaługi Filareta Amfiteatrowa, który w 1819 roku, odwiedzając miejscowy klasztor, zdecydował o budowie w jego pobliżu skitu - miejsca odosobnienia dla mnichów gotowych na prowadzenie samotnego życia naznaczonego głęboką modlitwą i wzmożoną ascezą. Wkrótce potem do Optyny przybyli starcy z lasów rosławskich, którzy rozpoczęli budowę pustelni. Okres świętych starców optyńskich, charakteryzujący się otwarciem posługi na ludzi świeckich, zapoczątkował starzec Leonid pod koniec lat dwudziestych XIX wieku (Kamiński, 2014, ss. 69, 71). Siedziba starców stała się miejscem pielgrzymek dla ludzi z różnych warstw społecznych. Pustelnię Optyńską odwiedzali również intelektualiści: Mikołaj Gogol, Fiodor

\footnotetext{
${ }^{2}$ Kwestie związane z ciałem za życia rozważam, opierając się na książce Ireneusza Cieślika Starcy Pustelni Optyńskiej (Cieślik, 2012), pracy Andrzeja Kamińskiego Starczestwo. Kierownictwo duchowe w Rosji w XIX wieku (Kamiński 2014), krótkim żywocie starca Serafina z Sarowa napisanym przez Joanna Kołogriwowa pt. O świętym starcu Serafinie (Kołogriwow, 2008), pracy Święty Serafim Sarowski. Żywot i pouczenia (1999) oraz tekstach powstałych w XIX wieku - Ogień Ducha Świętego (2008) i Opowieści pielgrzyma (1999). Druga część artykułu, dotycząca ciała tuż po śmierci, jest przedstawiona na podstawie Braci Karamazow Fiodora Dostojewskiego, natomiast nad zagadnieniami związanymi z relikwiami zastanawiam się, analizując relacje z kanonizacji starca Serafina z Sarowa zamieszczone w polskiej prasie.
} 
Dostojewski oraz Lew Tołstoj, by wymienić tylko tych najwybitniejszych ${ }^{3}$. Osobisty kontakt ze starcami był szczególnie ważny dla rosyjskich słowianofilów. Czołowy przedstawiciel tego nurtu, Iwan Kiriejewski, pomagał w działalności wydawniczej starcowi Makaremu. Słowianofile poszukujący w rosyjskiej duchowości pierwiastków irracjonalnych, odróżniających Rosję od Europy Zachodniej, znaleźli je w Optynie. Niewątpliwie na odczuwanie przez przybywających do klasztoru podróżnych wrażenia tajemniczości miało wpływ jego usytuowanie. Jak pisze Orlando Figes, nakreślając romantyczną wizję położenia klasztoru i jego oddziaływania na pątników:

W XIX wieku monastyr był odcięty od świata, nie można było doń dojechać koleją ani powozem, a pielgrzymi, którzy przybywali do świętego sanktuarium łodzią lub na piechotę, albo też czołgając się na kolanach, często doznawali uczucia, jakby cofnęli się w czasie (Figes, 2010, s. 222).

Do starców przybywało się „po słowo” (Cieślik, 2012, s. 13), zazwyczaj mogące pomóc w trudnej sytuacji życiowej. Praktykowany przez nich zwyczaj „odkrywania myśli” (kardiognoza) był uważany przez przeciwników starczestwa za herezję dotyczącą sakramentu spowiedzi, co mogło powodować napięcie pomiędzy starcem, a nieprzychylnymi mu współbraćmi ${ }^{4}$. Znajduje to odbicie w powieści Dostojewskiego.

W schyłkowych latach istnienia Związku Radzieckiego odradzająca się po trudnych doświadczeniach komunizmu Rosyjska Cerkiew Prawosławna uznała starczestwo za nieodłączną część swojej tradycji. Wyrazem tego była kanonizacja Ambrożego z Optyny w 1988 roku. Pozostali starcy optyńscy zostali zaliczeni do grona świętych osiem lat później. Należy przy tym zaznaczyć za Jarosławem Charkiewiczem, że kanonizacja nie jest początkiem kultu danej osoby, a jego oficjalnym uprawomocnieniem (Charkiewicz, 2010a, s. 156). Nie inaczej było w przypadku starców optyńskich, których kult zaczął rozwijać się na wiele lat przed ich kanonizacją.

Rozważanie kwestii cielesnych związanych z prawosławnym monastycyzmem nie mogłoby się obejść bez przywołania poglądów starożytnych Ojców Pustyni - praktyków i teoretyków ascezy - mających fundamentalny wpływ na postrzeganie ciała w ortodoksyjnym chrześcijaństwie. W sposobach określania stosunku do ciała późnoantycznych

\footnotetext{
${ }^{3}$ Więcej na temat roli, jaką Pustelnia Optyńska odegrała w życiu wymienionych pisarzy: zob. Ochał, 1994, ss. 258-266 oraz Cieślik, 2012, ss. 149-156.

${ }^{4}$ Przykładem jest sprawa starca Leonida, którego posługa została na pewien czas zawieszona przez biskupa Kaługi, zob. Cieślik, 2012, ss. 18-19, 80-82.
} 
anachoretów można wyróżnić dwa zasadnicze nurty. Pierwszy z nich, reprezentowany przez św. Antoniego Wielkiego (zm. 356), inspirowany platońskim poglądem uważającym ciało za więzienie duszy, traktował ascezę jako zakwestionowanie fizycznego charakteru ciała z jego wszystkimi potrzebami. Ciało, bezwzględnie piętnowane, było pojmowane jako wróg doskonałej duszy. Pogarda dla ciała była równoznaczna z wywyższeniem ducha. W drugim nurcie, mniej radykalnym, asceza, nieodłącznie z pokorą, miała być środkiem służącym nie wyniszczeniu ciała, a uzyskaniu, poprzez uwolnienie się od zmysłowych żądz, wewnętrznej wolności (Łeńska-Bąk, 2008, ss. 72-84). Poglądy na ciało XIX-wiecznych rosyjskich starców miały źródło przede wszystkim w drugiej z wymienionych tradycji.

\section{CIAŁO ZA ŻYCIA}

Interesującym motywem pojawiającym się w pracach poświęconych XIX-wiecznym rosyjskim starcom jest ich choroba i cudowne wyzdrowienie w dzieciństwie. Przykładem może być upadek z dzwonnicy siedmioletniego Prochora (późniejszego św. Serafina), z którego chłopiec wyszedł bez szwanku (Święty Serafim Sarowski, 1999, s. 10). Podobnie ciężka, przebyta w młodzieńczym wieku, trwająca ponad trzy lata, nieleczona choroba zakończyła się objawieniem Matki Boskiej, uwalniającym cierpiącego od fizycznego schorzenia (Kołogriwow, 2008, s. 9). Niechęć do leczenia ciała Prochor argumentował tym, że życie swoje oddał "jedynemu prawdziwemu lekarzowi, Jezusowi Chrystusowi i Przenajświętszej Bogarodzicy” (Święty Serafim Sarowski, 1999, s. 15). Podobny motyw można znaleźć w przedstawionym przez Ireneusza Cieślika żywocie św. Ambrożego z Optyny, dla którego przebyta choroba była ponadto impulsem do przyrzeczenia wybrania życia zakonnego (Cieślik, 2012, s. 109). Ciała przyszłych świętych już zatem w dzieciństwie przedstawiane są jako otoczone boską opieką, lecz nie przypisuje się im jeszcze nadnaturalnych, cudotwórczych właściwości. Warto zwrócić uwagę na stosunek starców do chorób ciała. Interesujące jest, cytowane przez Ireneusza Cieślika, zdanie wypowiedziane przez św. Ambrożego: „chorowanie jest pożyteczne dla mnicha. Z choroby nie należy się leczyć, a tylko ją podleczać" (Cieślik, 2012, s. 113). Stan chorobowy, podobnie jak umartwianie ciała, pozwalał na zachowanie dystansu wobec życia doczesnego. Nie jest to jednak zanegowanie ciała, a wykorzystanie go jako środka do osiągnięcia wartości duchowych. Również starzec Makary, spełniając kierownictwo duchowe wobec dwóch młodych mniszek - jego siostrzenicy oraz jej współsiostry - w adresowanych do nich listach, przeanalizowanych przez Andrzeja Kamińskiego, wskazuje, że choroba 
pełni funkcję korzystną dla życia wewnętrznego. Ponadto, według św. Makarego, choroba mniszki nie była przypadkowa, lecz zesłana przez Chrystusa, który „posłał (...) chorobę ciała dla oczyszczenia ducha". Makary wyraził współczucie dla adresatki oraz zapewnił ją, że sam Bóg nadał sens jej chorobie (Kamiński, 2014, ss. 166-167). Starzec nie pochwalał dobrowolnych działań mających na celu pogorszenie stanu zdrowia. W liście do siostrzenicy podkreśla, że jej brak troski o własne zdrowie byłby dla niego bardzo przygnębiający (Kamiński, 2014, s. 127). Na wyjątkowe znaczenie odczuwania bólu w prawosławiu zwrócił uwagę niemiecki teolog Walter Nigg. Jego słowa, które w zupełności można odnieść do postawy rosyjskich starców, przytoczę za Andrzejem Kamińskim: „Cierpienia nie traktuje się w rosyjskim chrześcijaństwie tylko jako kary przynoszącej ból. Dla prawosławnych ma ono o wiele szersze znaczenie. Odgrywa wręcz uzdrawiającą rolę, pozytywnie wartościując zrządzenie nieba" (cyt. za: Kamiński, 2014, ss. 101-102). Pożądanie choroby może być jednak zależne od stopnia jej nasilenia. Ciężko chory starzec Leonid, zbliżając się do śmierci, „prosił braci o modlitwę za niego, by Bóg skrócił jego cierpienia" (Cieślik, 2012, s. 83).

Twierdzenie starca Serafina z Sarowa zawarte w spisanym przez jego ucznia Mikołaja Motowiłowa dziele pt. Ogień Ducha Świętego ${ }^{5}$, że post jest zaledwie jednym ze środków służących zdobywaniu Ducha Świętego, najważniejszemu, według niego, celowi życia chrześcijanina, nie łagodzi bynajmniej surowości metod ascetycznych, które występują w opowieściach o świętym:

Żywił się jedynie czerstwym chlebem, dostarczanym mu w określonym terminie, i warzywami, które sam hodował i przyrządzał. Później przestał jeść nawet je i żywił się już tylko gorzkim ziołem zwanym tam „snitka”. W środy i piątki nie jadł w ogóle niczego. (...) Żył bez oświetlenia i bez ognia, nawet podczas najsurowszych zim. Pozwalał sobie jedynie na krótki sen, bezpośrednio na gołej podłodze (Kołogriwow, 2008, ss. 11-12).

Ponadto trwające tysiąc dni milczenie połączone z klęczeniem na kamieniu, będące odpowiedzią na targające mnichem pokusy, noszenie przez dziesięć lat żelaznego krzyża na ramionach, napaść zbójców, na skutek której postać Serafina stała się nieodwracalnie przygarbiona, to także ważne elementy kształtujące obraz świętości przez pryzmat trudnych doświadczeń ciała. Ciało pochylone symbolizuje pokorę, mającą być istotą postawy życiowej rosyjskich starców. Można przypuszczać, że zakres społecznego oddziaływa-

\footnotetext{
${ }^{5}$ Wydanym przez Sergiusza Nilusa siedemdziesiąt lat po śmierci starca Serafina, w roku 1903, tuż przed jego kanonizacją. Zob. Notatka Sergiusza Nilusa w: Św. Serafin z Sarowa, 2008, ss. 99-101.
} 
nia wizerunków przedstawiających starca Serafina ${ }^{6}$, rozpowszechnianych wśród rosyjskich chłopów, był szeroki. Świadczy o tym przywołana przez Ludwika Bazylowa opinia zaczerpnięta z pamiętników działacza ziemskiego Aleksandra Sawieliewa, która donosi o powszechności graficznych przedstawień świętego w chłopskich chatach (Bazylow, 1966, s. 279). Warto dodać, że z woli cara Mikołaja II podobizny sarowskiego starca otrzymywali rosyjscy żołnierze uczestniczący w wojnie z Japonią (Nicholas, 1992, s. 222; Witte, 1921, s. 130). W obliczu ponoszonych przez Rosję porażek, obdarowywanie żołnierzy obrazkami z wizerunkami świętych przez cara zostało gorzko spuentowane przez generała Michaiła Dragomirowa: „atakujemy Japończyków ikonami, podczas gdy oni używają przeciwko nam kul" (Witte, 1921, s. 130) 7 .

Interesujący fragment relacji Motowiłowa, w którym on oraz św. Serafin doświadczają nawiedzenia przez Ducha Świętego, naprowadza na kolejną godną uwagi kwestię. Obecność Ducha Świętego jest dla nich obu odczuwalna poprzez zmysły - dotyku, węchu i wzroku. Przyjemne ciepło, które czują, chroni ich od chłodnego, zimowego powietrza. Nadzwyczajny zapach Motowiłow charakteryzuje słowami:

Nic, co ziemskie, nie wydaje podobnego zapachu. Za życia mojej matki lubiłem tańczyć, jeździłem na bale i wieczorki taneczne i zdarzyło się, że matka spryskała mnie perfumami, które kupowała w najlepszych sklepach Kazania, ale tamte perfumy nie wydawały takiego zapachu... (Św. Serafin z Sarowa, 2008, s. 89).

Doznania starca Serafina i Motowiłowa nie należą do porządku ziemskiego, lecz do nadprzyrodzonego. Świadczą o tym słowa tego pierwszego: „żadna przyjemność płynąca z ziemskiego zapachu nie może być porównana z tym zapachem, jaki teraz odczuwamy, gdyż otacza nas teraz woń Świętego Ducha Bożego" (Św. Serafin z Sarowa, 2008, s. 90). Powiązanie doświadczania obecności istoty boskiej z wrażeniami zmysłowymi znajduje odbicie w śpiewie z prawosławnej liturgii: „Ciepłem Ducha Twego Świętego ogrzej mnie!” o czym Serafin informuje swojego ucznia. Posługiwanie się metaforyką odnoszącą się do doświadczeń zmysłowych wzmacnia poczucie realności boskiego działania. Zjednoczone z duszą ciało zostaje włączone w sferę sacrum. Człowiek osiąga stan przebóstwieniå.

\footnotetext{
${ }^{6}$ Niewykluczone, iż w wyżej wymienionych sytuacjach - zob. ilustracje zamieszczone w: Święty Serafim Sarowski, 1999, ss. 17-18.

7 "We are attacking the Japanese with icons (...) while they use bullets against us" (Witte, 1921, s. 130).

8 „Przebóstwienie (gr. theosis) to kluczowa kategoria teologii prawosławnej, zakładająca możliwość zjednoczenia się człowieka z Bogiem już tu i teraz, w myśl słów św. Atanazego Aleksandryjskiego »Bóg stał się człowiekiem, aby człowiek mógł stać się Bogiem«" (Przybył, 2006, s. 94).
} 
Związaną z wpływem Ducha Świętego, charakterystyczną cechą objawiającą się w wyglądzie rosyjskich starców, często pojawiającą się w dotyczących ich tekstach, jest promieniujące oblicze, silnie oddziałujące na wyobraźnię obserwatorów. Motowiłow nie jest w stanie skupić wzroku na rozjaśnionej twarzy św. Serafina - „Nie mogę, ojcze, patrzeć (...) bo z oczu ojca padają błyskawice. Twarz ojca stała się jaśniejsza od słońca, oczy bolą od blasku!" (Św. Serafin z Sarowa, 2008, s. 85). Interesujące, że może to być związane ze słabnięciem ciała - im słabsze ciało, tym silniej promieniuje. Ireneusz Cieślik przytacza następujące słowa archiprezbitera Pawła Lewaszewa, który odwiedziwszy umierającego starca Józefa, ucznia i następcę Ambrożego Optyńskiego, nie mógł oderwać od niego oczu: „(...) żegnałem się ze starcem może z dziesięć razy, bo wciąż patrzyłem na jego promieniujące oblicze, rozświetlone anielskim uśmiechem i światłem z innego świata" (Cieślik, 2012, s. 145).

Kolejną kwestią, o której należy wspomnieć, jest psychosomatyczny aspekt praktykowanej przez starców Modlitwy Jezusowej, polegającej na wielokrotnym wzywaniu imienia Jezusa, połączonym z odpowiednią kontrolą oddechu. Celem jest osiągnięcie stanu „nieustannej modlitwy", już pozbawionej słów (Przybył, 2006, ss. 105-106). O Modlitwie Jezusowej traktuje dzieło powstałe najprawdopodobniej pomiędzy 1855 a 1861 rokiem, pod tytułem Opowieści pielgrzyma. Utwór opowiada o wędrowcu szukającym u starca wskazówek mających pomóc mu w doskonaleniu sztuki modlitewnej. Nie wiadomo, kto jest jego autorem (Galiński, 1999, s. 7). Pouczenia bezimiennego "nauczyciela spraw duchowych" przyniosły upragniony rezultat. Pielgrzym, przywykły już do modlitwy, entuzjastycznie opisuje uczucia jej towarzyszące: „Jakże mi było lekko i radośnie, gdy ją zacząłem, język i usta wymawiały ją jakby same, bez mojego przymuszania! Cały dzień przeszedł mi pośród wielkiej radości, a czułem się tak, jakbym był wolny od wszystkiego, jakbym był na innej ziemi..." (Opowieści pielgrzyma, 1999, s. 33). Modlący się, dzięki odpowiednio dużej liczbie powtórzeń wezwania boskiego imienia, dąży do wypracowania mimowolności rytuału modlitwy. Wypowiada słowa bezwiednie, wywołując złudzenie utraty kontroli nad własnym ciałem.

\section{CIAŁO TUŻ PO ŚMIERCI}

"Czekam na połajanki krytyków" - to prowokacyjne zdanie zawarte przez Dostojewskiego w liście z 21 sierpnia 1879 roku do Konstantego Pobiedonoscewa, oberprokuratora Świętego Synodu Rządzącego, informującym o ukończeniu szóstej księgi Braci Karamazow zatytułowanej Rosyjski mnich, poświadcza, że powieściopisarz doskonale zdawał sobie 
sprawę z kontrowersyjności tekstu. "Tę księgę pisałem dla niewielu i uważam ją za kulminacyjny punkt powieści" - można przeczytać w tym samym liście, wysłanym z Ems, gdzie schorowany, zbliżający się nieuchronnie do końca życia pisarz przebywał na kuracji (Dostojewski, 1979, s. 547). W innym liście do Pobiedonoscewa, Dostojewski uskarżając się na scjentyzm i nihilizm, zaznacza, że jego zamiarem było uczynienie nauk starca Zosimy przeciwstawieniem dla owych idei („Albowiem ta szósta księga Rosyjski mnich (...) stanowi właśnie odpowiedź na cały ten nurt negacji"), z którymi nieustannie zmagał się w swojej twórczości. Kreując Zosimę jako uosobienie ideału pokornego życia chrześcijańskiego polegającego na bezwzględnym przebaczaniu bliźnim, Dostojewski był świadomy występującego przy tym ryzyka odrealnienia powieściowego starca. Podkreślając swoje przywiązanie do zasad literackiego realizmu, autor Braci Karamazow snuł rozważania w liście do Pobiedonoscewa:

Właściwie powinienem był przedstawić postać skromną i wzniosłą. Ale życie jest pełne komizmu, wzniosłe jedynie w sensie wewnętrznym, poniekąd więc z musu, ze względu na wymagania artystyczne, zmuszony byłem pisząc biografię mojego mnicha dotknąć najbardziej trywialnych stron życia, po prostu aby nie naruszyć artystycznych reguł realizmu (Dostojewski, 1979, s. 551).

Najprawdopodobniej słowa Dostojewskiego odnoszą się do zawartego w powieści żywota starca spisanego przez Aloszę Karamazowa. Nie ulega jednak wątpliwości, że owe, używając określenia pisarza, „najbardziej trywialne strony życia” związane ze starcem Zosimą najsilniej objawiły się w pierwszym rozdziale kolejnej księgi powieści (Alosza) zatytułowanym Odór trupi, przedstawiającym okoliczności towarzyszące pogrzebowi świątobliwego mnicha.

We wrześniu 1879 roku, ukończywszy ową księgę, Dostojewski przesłał arkusze do redakcji konserwatywnego dziennika „Russkij Wiestnik", w którym publikował w odcinkach swoje utwory. W dołączonym do arkuszy powieści liście skierowanym do redaktora czasopisma Mikołaja Lubimowa, obawiając się nadmiernej ingerencji redakcji w tekst z powodu uznania go za demoralizujący, pisarz usilnie prosił:

Błagam, Mikołaju Aleksiejewiczu, aby w tej księdze niczego Pan nie wykreślał. Nie ma zresztą czego, wszystko jest w porządku. Jest tylko jedno słowo (o trupie zmarłego): prześmierdł. Ale pada ono z ust ojca Feraponta, który nie może mówić inaczej. I gdyby nawet mógł powiedzieć: czuć go, to nie przeszłoby mu to przez gardło i powiedziałby: prześmierdł. Niech Pan mi to wybaczy, na litość Boga. Więcej nie ma. Może tylko proszek na wymioty. (Dostojewski, 1979, ss. 556-557). 
Usprawiedliwienia pisarza nie kończą się na przywołanym fragmencie. W dalszej części listu Dostojewski, „na wszelki wypadek”, uprzedza Lubimowa:

(...) proszę nie myśleć, na litość boską, że w swojej powieści pozwoliłem sobie chociażby na najmniejsze zwątpienie w cudowne działanie relikwij. Sprawa dotyczy jedynie relikwij zmarłego mnicha Zosimy, a to zupełnie inna rzecz. Podobny popłoch, jaki opisałem w moim monasterze, powstał kiedyś na Athosie i został krótko, ale ze wzruszającą naiwnością opisany w „Pielgrzymce mnicha Parfeniusza”. (Dostojewski, 1979, s. 557).

W carskiej Rosji wolność wypowiedzi była znacznie ograniczona, a pisarzy za poglądy wyrażone w dziełach literackich mogły spotkać represje. Najlepszym przykładem jest sprawa Lwa Tołstoja (zob. Szkłowski, 1967, ss. 677-679), obłożonego ekskomuniką m.in. z powodu powieści Zmartwychwstanie, przedstawiającej Rosyjską Cerkiew Prawosławną oraz carat jako sprzymierzone ze sobą, przepełnione obłudą i chciwością narzędzia ucisku rosyjskiego ludu. Nie dziwi zatem, że Dostojewski, pomimo swojej powszechnie znanej czci dla prawosławnej wiary, odczuwał potrzebę wytłumaczenia się "na wszelki wypadek" przed konserwatywnym środowiskiem „Russkiego Wiestnika”, że przedstawiony przez niego „skandal” (by użyć określenia Michaiła Bachtina ${ }^{9}$ ), nie jest czymś nadzwyczajnym, a jedynie odwzorowaniem historii zapisanej przez pochodzącego z Mołdawii mnicha ${ }^{10}$.

Wpływ pośmiertnego stanu ciała starca na jego desakralizację rozważę na podstawie interpretacji przywołanego fragmentu Braci Karamazow (rozdział pt. Odór trupi). Postaram się podać interpretację rozszerzającą stanowisko narratora powieści, że „brutalnie wyuzdane zgorszenie", jakie zapanowało wśród zakonników i ludzi z zewnątrz monasteru z powodu cuchnącej woni dobywającej się z trumny starca, spowodowała „niechęć do instytucji starców, jako szkodliwego nowinkarstwa” oraz "zawiść względem świętości nieboszczyka” (Dostojewski, 1984, ss. 390-391).

Oczekiwanie powieściowych mnichów oraz ludzi świeckich, zgromadzonych wokół trumny starca Zosimy, na cudowne wydarzenie, najpewniej ma miejsce z powodu utrwalonej

\footnotetext{
${ }^{9}$ Nie wchodząc w szczegóły subtelnych analiz literaturoznawczych dokonanych przez Michaiła Bachtina w fundamentalnym dla badań literackich nad twórczością Dostojewskiego dziele Problemy poetyki Dostojewskiego, przywołam jedynie słowa krótko charakteryzujące kategorię świata skarnawalizowanego, z której korzystał Bachtin, opisując prozę Dostojewskiego, przejawiającą się najsilniej w owych „epizodach skandalów i katastrof": „Wszystko to jest zaskakujące, niedorzeczne, urągające normom zwykłego życia. Niepodobna wyobrazić sobie takiego epizodu, na przykład, w powieściach Tołstoja lub Turgieniewa. To nie salon - to rynek karnawałowy z jego swoistą logiką „świata na opak". Przypomnijmy sobie wreszcie skandal w monasterze, u starca Zosimy (Bracia Karamazow) - epizod niezwykle barwny, nasycony kolorytem karnawałowo - mennipejskim". (Bachtin, 1970, s. 223).

${ }^{10}$ Krótki biogram mnicha Parfeniusza zob. w: http://www.pravoslavie.ru/english/46149.htm. O inspiracji Dostojewskiego dziełem mnicha Parfeniusza pisze również Margaret Ziolkowski (1988, ss. 157, 163).
} 
w prawosławiu tradycji, że śmierci świątobliwego starca towarzyszą nadprzyrodzone wypadki, których sprawcą jest jego niegnijące, a w niektórych przypadkach nawet wydające przyjemną woń ciało, symbolizujące bożą przychylność dla zmarłego (por. Święty Serafim Sarowski, 1999, s. 21; Dostojewski, 1984, s. 391)11. W pobliżu trumny zbierali się chorzy czekający na uzdrowienie. Cenna w tym kontekście uwaga Mircei Eliadego: „jeżeli znak się nie objawia, prowokuje się go. (...) Człowiek domaga się znaku aby położyć kres napięciu spowodowanemu przez względność oraz trwodze wynikającej z dezorientacji - jednym słowem - aby znaleźć absolutny punkt oparcia" (Eliade, 1974, s. 146), może być ciekawym tropem interpretacyjnym. Nie mogąc otrzymać znaku z niebios, żywi poddają zjawisko śmierci usensownieniu, nadając gnilnemu zapachowi - naturalnej właściwości trupa - znaczenie wyroku Opatrzności. Reakcja na nieuświadomiony lęk przed śmiercią objawia się w przypisaniu jej sensu boskiej interwencji („Widać sąd boży inny jest od ludzkiego. (...) skądże ten zaduch? Znaczy umyślnie chciał Bóg wskazać?") (Dostojewski, 1984, ss. 392-393). Śmierć w prawosławiu uważana jest za punkt graniczny, po którego przekroczeniu człowieka czeka kara lub nagroda (Belyaeva, b.d.). Sposób, w jaki został potraktowany trup starca Zosimy, przewrotnie wpisuje się w tę eschatologiczną koncepcję. Sąd nad zmarłym odbywa się bowiem nie w niebiosach, lecz na ziemi. Sankcja, jaka spotyka starca, jest symboliczna - ukarane zostaje jego ciało, które ze względu na niespełnienie kryterium świętości, za jakie większość zgromadzonych uznała niewydzielanie związanego z gniciem zapachu, zostaje zdesakralizowane. Słuszne spostrzeżenie francuskiego antropologa Louisa-Vincenta Thomasa, iż "dyskurs o trupie (...) zwrócony jest ku żywym" (Thomas, 1991, s. 58), prowadzi nas do stwierdzenia, że sąd nad trupem ma służyć przede wszystkim zebranym w celi starca. Ciało martwe znajduje się we władzy żyjących. Rozkładające się zwłoki stają się obiektem wywołującym określone

\footnotetext{
"Warta przytoczenia w tym miejscu jest uwaga L.-V. Thomasa: „zapach zmarłego, brak gnicia, a tym bardziej »słodki« zapach niektórych trupów obarczone zostały magiczno-religijnym znaczeniem" (Thomas, 1991, s. 72) oraz fragment Św. Idioty Cezarego Wodzińskiego mówiący o nadzwyczajnych znakach pojawiających się po śmierci jurodiwych: „Zdarza się, że śmierci jurodiwego towarzyszą inne cudowne znaki, jak »nieziemskie wonności, którymi wypełnia się całe miasto « w chwili odejścia Izydora z Rostowa, albo - co częściej bywa - potężne burze z gromami i błyskawicami o niespotykanej mocy. (...) Oczywiście, wkrótce po pogrzebie nawiedza świat inna burza - burza cudów i cudownych uzdrowień" (Wodziński, 2009, s. 71). Jako przykład konfliktu pomiędzy gnijącym ciałem a świętością, interesujący jest przypadek prawosławnej świętej Paraskiewy Bułgarskiej zmarłej w XI wieku. Jak podaje żywot świętej napisany w 1385 roku przez patriarchę Bułgarii Eutymiusza Tyrnowskiego, po śmierci mniszki jej ciało zostało pochowane w nieoznaczonym miejscu, niedaleko morza. Po pewnym czasie morze wyrzuciło na brzeg zwłoki żeglarza w stanie znacznego rozkładu. Na prośbę żyjącego w pobliżu słupnika, który nie mógł znieść zapachu rozkładających się zwłok, trup miał zostać pochowany. Podczas pracy grabarze znaleźli nienaruszone ciało św. Paraskiewy. Nieświadomi niezwykłości dokonanego odkrycia, pogrzebali zwłoki żeglarza wspólnie z niezniszczonym ciałem świętej. W nocy najbardziej pobożnemu z nich - Jerzemu - ukazała się cesarzowa siedząca na świetlistym tronie, otoczona przez promieniujących żołnierzy. Jeden z nich polecił mu, aby natychmiast pochował ciało św. Paraskiewy w zaszczytnym miejscu. Jaśniejąca pani, którą okazała się być sama święta Paraskiewa, również przemówiła do Jerzego, podkreślając, że nie może dłużej znieść woni gnijących zwłok. Następnego dnia relikwie świętej zostały przeniesione i od tego czasu czyniły mnóstwo cudów, uzdrawiając ludzi ślepych, chromych i dotkniętych chorobą psychiczną (Detelić, 2010, ss. 95, 101).
} 
fantazmaty u ludzi mających z nimi styczność, którzy podejmują manipulację trupem (myśl zaczerpnięta z: Thomas, 1991, s.51). Desakralizacja ciała zmarłego pozwala na dyskredytację jego osoby za życia: „Wierzył jakoś modnie, ognia materialnego w piekle nie uznawał. (...) Nie bardzo przestrzegał postów, dogadzał sobie: słodycze do herbaty jadał, wiśniowe konfitury, które mu paniusie przysyłały, bardzo to lubił. (...) Sakramentu spowiedzi nadużywał" (Dostojewski, 1984, s.394). Szczególnie druga z przywołanych wypowiedzi zdaje się aluzyjnie sugerować czytelnikowi obraz lubieżnego („paniusie”), łakomego („,wiśniowe konfitury”) i - co najważniejsze - grzesznego już nie świętego, a zwykłego śmiertelnika. Pozbawienie ciała zmarłego cech świętości było koniecznym zabiegiem umożliwiającym czynienie tego rodzaju uwag.

Okoliczności towarzyszące śmierci starca Zosimy zwabiają jego przeciwnika - jurodiwego ojca Feraponta - szalonego ascetę nieustannie tropiącego zgubne wpływy szatana. Stetryczały jurodiwy, przepasany powrozem, boso, z nagą piersią, podzwaniający noszonymi na ciele łańcuchami, zjawia się nagle, wkrótce po wspomnieniu go w myślach przez jednego z mnichów, jak gdyby na umówiony, telepatyczny znak, podsycając nieprzychylne zmarłemu starcowi emocje zgromadzonego tłumu. Tak, niewątpliwie jest to ten, który nie może na zaistniałą sytuację spojrzeć przez palce i nie ocenić jej dosadnym i szczerym stwierdzeniem: „prześmierdł”. „Opętany i porywczy mnich Ferapont, ścigający siłę nieczystą w każdym kącie; on także pretenduje do świętości i jego pretensje znajdują posłuch wśród wielu ludzi" - pisał Dostojewski w błyskotliwym, przytoczonym w całości przez Cezarego Wodzińskiego, liście do nieznanego z imienia i nazwiska początkującego pisarza, który nosząc się z zamiarem napisania traktatu poświęconego jurodstwu, zwrócił się do autora Braci Karamazow po poradę (Wodziński, 2009, ss. 14, 245). „Mój Bóg zwyciężył!” - krzyczy jurodiwy zalewając się łzami i padając na twarz, a roztkliwiony niniejszymi wypadkami tłum, potrzebujący nowego świętego w miejsce zniesławionego Zosimy, znajduje go w osobie ojca Feraponta („Oto kto święty! Oto kto sprawiedliwy! - wołano już bez lęku - oto kto winien być starcem...") (Dostojewski, 1984, s. 398). Pojawił się nowy punkt oparcia. Lęk został ujarzmiony.

\section{CIAŁO W POSTACI RELIKWII}

Aby rozważyć środki służące sakralizacji bądź desakralizacji ciała świętego w postaci relikwii, przyjrzę się relacjom z wydarzeń związanych z kanonizacją Serafina z Sarowa, zamieszczonym w polskiej prasie. Trzeba odnotować, iż reportaże, będące $w$ większości telegramami rosyjskiej agencji prasowej, zawierają wyraźny przekaz propagandowy. 
15 lutego 1903 roku$^{12}$, po zbadaniu przypadków cudownych uzdrowień dokonanych za sprawą Serafina z Sarowa oraz jego relikwii, Święty Synod ogłosił decyzję o zaliczeniu go do grona świętych. Szczątki starca miały zostać złożone w grobowcu ufundowanym przez Mikołaja II $^{13}$. Car miał znaczny wpływ na przyspieszenie procesu kanonizacji, która odbyła się pomimo początkowych zastrzeżeń Świętego Synodu (Freeze, 1996, s. 317) ${ }^{14}$. Wraz z rodziną był obecny w Sarowie już podczas otwarcia trumny starca Serafina, wpłacając przy tym 20.000 rubli na rzecz klasztoru15. Warto w tym miejscu przywołać słowa Louisa-Vincenta Thomasa celnie opisujące mechanizm wykorzystywania relikwii przez władzę: „relikwia (...) stwarza oparcie dla miejscowej władzy i przemawia językiem porządku i równowagi. (...) Osoba zmarłego jest w tym wszystkim jedynie zatartym i odległym instrumentem, przysłoniętym symbolami, jakich się zmarłemu udziela" (Thomas, 1991, s. 119).

Wypada tu również oddać głos Ludwikowi Bazylowowi, który w ironizującym tonie określił intencje cara dotyczące kanonizacji: „przeprowadzić imprezę, która by utrwaliła wiarę w masach, przede wszystkim na wsi i wpłynęła na »zacieśnienie jedności między carem i narodem «" (Bazylow, 1966, s. 279). Uroczystości kanonizacyjne były drobiazgowo zaplanowanym spektaklem. Postarano się nawet o rekonstrukcję wnętrza celi starca Serafina (Zob. podpis pod ilustracją, Święty Serafim Sarowski, 1999, s. 20). Na drodze, którą przemierzyła wyjeżdżająca z Sarowa carska rodzina, jak podaje telegram wydrukowany w "Słowie", ustawiono prowizoryczne słomiane łuki triumfalne ozdobione narzędziami rolniczymi, a chłopskie chaty zostały udekorowane chustami i flagami ${ }^{16}$. Przaśność całego przedsięwzięcia połączona z matactwami przy ustalaniu listy domniemanych cudów skłoniła Bazylowa do konstatacji, iż "więcej było w Rosji kpin z tej okazji niż »utrwalania się jedności cara i narodu«" (Bazylow, 1966, s. 279). Abstrahując od społecznego odbioru wydarzeń mających miejsce w Sarowie latem 1903 roku, należy stwierdzić, że kanonizacja św. Serafina była jednym z istotnych elementów służących odrodzeniu zespolonego z caratem mitu Świętej Rusi, kluczowego dla programu propagandowego Mikołaja II (Nicholas, 1992, s. 212). Odpowiedź cara na radykalizujące się nastroje społeczne w Rosji

\footnotetext{
${ }^{12}$ Daty dzienne podaję według kalendarza gregoriańskiego.

13 Zob. „Gazeta Polska” 16.02.1903, 46, s. 3.

${ }^{14}$ Siergiej Witte (1921, ss. 204-205) wspomina opowiedzianą mu osobiście przez Pobiedonoscewa rozmowę pomiędzy nim a parą cesarską, dotyczącą zalecenia, by jak najszybciej przeprowadzić kanonizację starca Serafina.

15 Zob. "Gazeta Polska” 19.11.1903, 317, s. 3.

${ }^{16}$ Zob. „Słowo” 03.08.1903, 175, s. 3.
} 
na początku XX wieku polegała na wykorzystaniu szczątków sarowskiego starca do celów ideologicznych ${ }^{17}$.

Przechodząc do opisu głównych uroczystości kanonizacyjnych, warto zwrócić uwagę, że car był jednym z niosących trumnę zawierającą relikwie św. Serafina ${ }^{18}$. To ważny element propagandowy, prezentujący uczestnikom uroczystości Mikołaja II jako sługę prawosławia, uniżonego wobec świętości sarowskiego starca. Z pewnością tego rodzaju zabieg wywierał duże wrażenie na zgromadzonych w Sarowie pielgrzymach, których liczba, według rosyjskiego telegramu ogłoszonego drukiem w polskiej prasie, przekroczyła 300 tysięcy ${ }^{19}$. Bez wątpienia widok cara dźwigającego na ramionach relikwie świętego starca był komunikatem zrozumiałym dla prostej ludności, nieufnej wobec abstrakcyjnych pojęć charakteryzujących oficjalne doktryny religijne i państwowe, a chętnie manifestującej zewnętrzne przejawy religijności ${ }^{20}$.

W sposobie opisywania reakcji ludności rosyjskiej na widok trumny ze szczątkami świętego („Ujrzawszy trumnę, masy padały na ziemię, wielu płakało."21) oraz opuszczającego Sarowo Mikołaja II („Kiedy wracając od źródła Najjaśniejszy Pan szedł przez las i wszedł między lud, cały olbrzymi tłum padł na kolana, ze łzami radości i błogości."222) widać wyraźne podobieństwo. Uświęcające osobę cesarza, ścisłe podporządkowanie Cerkwi państwu, nasilające się od czasów Piotra I, kiedy w miejsce zawieszonego patriarchatu moskiewskiego kierownictwo nad Cerkwią przejął Święty Synod Rządzący, znajdowało odbicie w świadomości rosyjskiego ludu. „Zapału pobożnych, widzących Ubóstwianego Ojca-Cesarza w pobliżu opisać, niepodobna" - możemy przeczytać w telegramie wydrukowanym w "Gazecie Handlowej"23. Jak piszą Borys Uspienski i Wiktor Żywow, tłumacząc owo zjawisko: „(...) wraz ze zlikwidowaniem patriarchatu monarcha przejął funkcję patriarchy, co bezpośrednio odbiło

\footnotetext{
${ }^{17}$ O politycznym wymiarze kanonizacji przeprowadzonych za panowania Mikołaja Il pisze Gregory L. Freeze (1996, ss. 308-350). Oprócz kanonizacji św. Serafina z Sarowa omawia kanonizacje św. Jana Maksymowicza oraz św. Hermogena, traktując je jako działania mające na celu odnowienie sakralnej legitymizacji władzy carskiej w obliczu kryzysu społecznego w Rosji.

${ }^{18}$ Zob. "Kurier Warszawski” 02.08.1903, 211, s. 7.

${ }^{19}$ Zob. "Słowo" 01.08.1903, 174, s. 4. Ludwik Bazylow kwestionował ten szacunek, twierdząc, że został zawyżony (Bazylow, 1966, s. 280).

20 "Religia ludu miała niewiele wspólnego z książkowym chrześcijaństwem duchowieństwa. Jako człek z reguły niepiśmienny, dziewiętnastowieczny chłop rosyjski znał Ewangelię bardzo słabo, bo na wsi nie było tradycji wygłaszania kazań. (...) Przeciętny chłop niejasno rozumiał pojęcia nieba i piekła i bez wątpienia liczył, że wierne przestrzeganie kościelnych obrzędów zapewni mu zbawienie duszy. Ale inne pojęcia abstrakcyjne były mu zupełnie obce". (Figes, 2010, s. 242). Więcej na temat specyfiki chłopskiej religijności w XIX-wiecznej Rosji zob. Piekarska-Winkler, 2001, ss. 124-127.

${ }^{21}$ Zob. „Kurier Warszawski” 02.08.1903, 211, s. 7.

22 Zob. „Słowo" 03.08.1903, 175, s. 3.

${ }^{23}$ Zob. "Gazeta Handlowa” 03.08.1903, 174, s. 2.
} 
się na rozumieniu funkcji cara. (...) Jeżeli początkowo koncepcja monarchy, jako obrazu Bożego oparta była na źródłach spisanych, to stopniowo, jak można sądzić, staje się faktem świadomości religijnej"24 (Uspienski \& Żywow, 1992, s. 71, 77). Należy dodać, że wpływ na jeszcze silniejsze zrośnięcie się caratu z Cerkwią w świadomości ludności rosyjskiej mogła mieć doktryna stworzona za panowania Mikołaja I przez długoletniego ministra oświaty Imperium Rosyjskiego Siergieja Uwarowa (zm. 1855), wyrażająca się w formule prawosławie - samodzierżawie - narodowość ${ }^{25}$. Uwarow, chcąc przyczynić się do uniknięcia przez Rosję rewolucji społecznych, które począwszy od Wielkiej Rewolucji Francuskiej co jakiś czas wstrząsały zachodnią Europą, przekonywał, że głęboka, prawosławna wiara ludu rosyjskiego jest gwarantem pomyślnego funkcjonowania władzy państwowej, a harmonijne współistnienie carskiego samodzierżawia oraz Cerkwi jest wyłącznym warunkiem prawidłowego rozwoju rosyjskiego narodu (Pawełczyk-Dura, 2012, ss. 195-196) ${ }^{26}$.

Podczas uroczystości kanonizacyjnych żyjąca, fizyczna postać monarchy była adorowana na równi z martwymi relikwiami św. Serafina z Sarowa. Nie jestem w stanie rozstrzygnąć, w jakim stopniu relacje odbijają autentyczne zachowania społeczeństwa rosyjskiego, a jak bardzo są świadectwem tendencyjności przekazów wywyższających cara ${ }^{27}$.

Nie bez znaczenia jest również uczta z udziałem rodziny carskiej oraz wysokich dostojników państwowych i kościelnych, która odbyła się podczas uroczystości. Partycypacja we wspólnym posiłku zarówno przedstawicieli tronu, jak i ołtarza, jest symbolicznym wyrazem przymierza, potwierdzającym nierozerwalność obu sfer. Odbywające się dziesięć dni przed głównymi ceremoniami przedkanonizacyjne obrzędy przeniesienia relikwii można potrak-

\footnotetext{
${ }^{24}$ Uspienski i Żywow podają przykłady potwierdzające ich tezę ( $w$ którą wpisują się również podane przeze mnie opisy reakcji ludności chłopskiej na widok cara Mikołaja II): „Charakterystyczny jest przypadek, o którym pisze Katarzyna II w liście do N. I. Panina z 26 maja 1767 roku: „»W jednej miejscowości po drodze chłopi dawali świece, aby je stawiać przede mną, ale ich przegoniono«. (Sołowjew, XIV, s. 52). Widocznie chłopi brali cesarzową za żywą ikonę. O takim samym rozumieniu świadczy we swych wspomnieniach W. A. Rotkirch, opisując, jak żołnierze odpowiadali na pozdrowienie Mikołaja l i żegnali się pobożnie »jak przy dźwięku dzwonów na jutrznię paschalną«; później, podróżując razem z Aleksandrem II koleją, tenże autor miał możność obserwowania, jak carski pociąg spotykali dróżnicy kolejowi przy swoich budkach: »dróżnicy z całymi rodzinami żegnali się i bili pokłony przed swoim ziemskim bogiem « („Russkaja Starina” 19:1889, kwiecień, s. 52)” (Uspienski \& Żywow, 1992, s. 77).

${ }^{25}$ Nazwaną później teorią oficjalnej narodowości. Zob. Pawełczyk-Dura, 2012, s. 195.

${ }^{26}$ Por. Freeze, 1996, s. 315.

${ }^{27}$ Dla kontrastu warto przywołać opinię Lwa Tołstoja, który w liście do Mikołaja II z 16 stycznia 1902 roku przestrzegał go przed złudzeniem, że entuzjastyczne powitania ludu rosyjskiego, jakich doświadczał, są dowodem miłości wobec niego. „Nie wierz temu, że jest to wyraz wierności wobec Ciebie - nie, to tłum gapiów, który pobiegnie tak samo za każdym niecodziennym widowiskiem. Często nawet ci ludzie, których uważasz za wyrazicieli miłości narodu do Ciebie, są niczym innym jak zebranym przez policję i podmówionym tłumem, mającym udawać oddany Ci naród..." (Tołstoj, 1976, s. 198). Fragment niniejszego listu Tołstoja został przytoczony w polskim wydaniu pamiętnika Mikołaja II (zob. Pamiętnik Mikotaja II, 1990, ss. 65-66.)
} 
tować jako powtórny pogrzeb starca Serafina - jego szczątki zostały wówczas złożone w nowym, ufundowanym przez cara grobowcu (zob. Święty Serafim Sarowski, 1999, s. 29). Biorąc pod uwagę silnie zakorzenioną w rosyjskiej kulturze tradycję spożywania pokarmów na grobach zmarłych, słuszna wydaje się być interpretacja uczty jako spóźnionej stypy, której ranga została podniesiona poprzez obecność rodziny cesarskiej.

W telegramie "Gazety Kaliskiej" jest opis cudownego działania, jakie przypisuje się relikwiom, objawiającego się w funkcji leczniczej, zdający się mieć na celu uprawomocnienie kanonizacji natychmiast, tuż przed rozpoczęciem uroczystości:

Przy źródle nieobliczony tłum. Cuda powtarzają się co tydzień. Na trzeci dzień 12-letni chłopiec głuchoniemy wyzdrowiał. Ślepy od urodzenia 3-letni chłopiec odzyskał wzrok, a dziewczynka głuchoniema przemówiła przy wszystkich. Fakty wyleczenia się potwierdzane są przez dyżurnych oficerów i świadków z ludu. (...) Upał straszny. 30-letnia kobieta wyleczyła się na chorą rękę. Pełzający mężczyzna począł chodzić ${ }^{28}$.

Cudowne działanie świętego starca nie ominęło również pary cesarskiej. Pod osłoną nocy cesarzowa Aleksandra obmyła się wodą ze źródła, z którego św. Serafin czerpał wodę za życia. Bezowocnie, jak dotąd, wyczekujący syna, Mikołaj i Aleksandra byli zgodni co do tego, że nocna kąpiel w cudownym źródle umożliwiła poczęcie cesarzewicza Aleksego (ur. 1904) (zob. Witte, 1921, s. 205) ${ }^{29}$.

Rozszerzenie zaledwie wzmiankowanych przez Bazylowa kontrowersji wokół kanonizacji Serafina z Sarowa możemy znaleźć w warszawskiej prasie ${ }^{30}$. Wspomniany przeze mnie we wstępie artykuł "Gazety Polskiej" z 7 lipca 1903 roku, przytaczający tłumaczenie wypowiedzi metropolity Petersburga Antoniego ${ }^{31}$ zamieszczonej w stołecznym dzienniku „Nowoje Wremia”, informuje słowami biskupa o tajemniczym „związku walki z prawosławiem”

${ }^{28}$ Zob. „Gazeta Kaliska” 30.07.1903, 209, s. 3. Więcej na temat pielgrzymów oczekujących na cudowne uzdrowienie zob. Freeze, 1996, s. 325.

${ }^{29}$ Kąpiel w sarowskim źródle zalecił Aleksandrze francuski szarlatan Philippe, pełniący na dworze cesarskim funkcję podobną do tej, jaka później przypadła Rasputinowi (Price, 2011, ss. 354, 360).

${ }^{30}$ Pisze o nich również Richard Price, który nadmienia, że Synod natychmiast po otwarciu trumny wydał oświadczenie, że nierozkładalność zwłok nie jest koniecznym warunkiem świętości (Price, 2011, s. 349; por. Freeze, 1996, s. 321). Price zaznacza, że fakt całkowitego rozkładu ciała św. Serafina „dostarczył amunicji sceptykom” („provided ammunition for the sceptics"). Odmiennie niż Bazylow, twierdzi, że kontrowersje związane z kanonizacją, nagłaśniane przez przeciwników Cerkwi i caratu, nie zmniejszyły entuzjazmu ludu, ponieważ liczba pielgrzymów w Sarowie była większa niż zakładano przed rozpoczęciem uroczystości (Price, 2011, s. 349). Gregory L. Freeze zaznacza, że wśród członków komisji Świętego Synodu, powołanej w celu ustalenia listy cudów dokonanych za sprawą starca Serfina, zaistniał spór dotyczący kwestii upublicznienia faktu rozkładu jego zwłok. Wstępny szkic raportu komisji nie uwzględniał tej okoliczności, a nawet „stwarzał zwodnicze wrażenie, że szczątki Serafina pozostały nienaruszone" ("created misleading impression that Serafim's remain were intact") (Freeze, 1996, s. 320).

${ }^{31}$ Przewodniczącego uroczystościom kanonizacyjnym św. Serafina. 
rozpowszechniającym ulotki w Petersburgu, w których domagał się zbadania szczątków sarowskiego starca ${ }^{32}$. Rozprowadzane broszury były nie tyle powodem zawiązania się szerokiej dyskusji społecznej, co raczej jej emanacją: „Zresztą, pomimo kartek, o relikwiach starca Serafina toczy się wiele lekkomyślnych rozmów nawet między ludźmi wykształconymi, dobrze myślącymi i wierzącymi". Metropolita Antoni, z wyraźnym lekceważącym pobłażaniem odnoszącym się do prowokatorów, wyjaśnia, że nie poczuwałby się do obowiązku zabrania głosu w tej sprawie, gdyby nie „nieprzyzwoita wzmianka o zawartości trumny" znajdująca się w ulotkach. Duchowny bez skrępowania przyznaje, że „w trumnie pod resztkami zmurszałej szaty zakonnej widnieje szkielet spoczywającego starca. Ciało uległo zepsuciu. Kości i włosy na głowie i brodzie zachowały się w całości"³3. Klasyfikując ludzi uznających stan zachowania relikwii za kryterium świętości jako nierozsądnych, wzmacniając ponadto merytoryczność swej wypowiedzi przywołaniem opinii znawcy historii prawosławnych kanonizacji, profesora Eugeniusza Gołubińskiego, staje na stanowisku, iż nierozkładalność ciała nie jest jej koniecznym warunkiem. Może być jedynie dodatkiem, niewpływającym na rozstrzygający wykładnik, czyli zdolność szczątków do czynienia cudów, niezależną od stopnia ich rozkładu ${ }^{34}$. Tekst biskupa Antoniego ma również na celu podniesienie rangi jedynej fizycznej pozostałości po starcu Serafinie - jego kości. Odzwierciedla to obecny w prawosławiu pogląd, że to nie w ciele, a w kościach koncentruje się siła ludzkiego organizmu ${ }^{35}$. Nie da się zapobiec, bez stosowania odpowiednich środków konserwujących, naturalnemu rozkładowi ciała po śmierci. Biorąc pod uwagę zapotrzebowanie na świętych wśród wierzących (oraz władców), brak pośmiertnego gnicia ciała nie może być uznawany za decydujący miernik świętości.

Nie ulega wątpliwości, że człowiek żyjący w modernizującym się społeczeństwie podważa realność istnienia sfery sacrum. Utożsamiając ją z władzą, świecką oraz duchowną, pragnie zdemaskować symbole uosabiające instytucje starego, feudalnego porządku. Znów

${ }^{32}$ Artykuł biskupa Antoniego oraz akcję „związku walki z prawosławiem” krótko omawia Gregory L Freeze. Zbadane przez niego akta policyjne informują, że związek, obawiając się pomyślnego dla cara przebiegu uroczystości kanonizacyjnych, zamierzał wydać całą serię nielegalnych pism i rozprowadzać je wśród pielgrzymów. (zob. Freeze, 1996, ss. 321-322.)

${ }^{33}$ Zob. „Gazeta Polska” 07.07.1903, 183, s. 2. Interesująca jest wzmianka w artykule Freeze'a, informująca, że konserwatywni duchowni przez długi czas krytykowali biskupa Antoniego za podanie do publicznej wiadomości szczegółów dotyczących stanu zachowania relikwii św. Serafina (Freeze, 1996, s. 322, przyp. 56).

${ }^{34}$ "Dowód świętości świętych stanowią cuda, które objawiają się przy ich trumnach lub relikwiach, bez względu, czy zwłoki są całe, czy też istnieją tylko pozostałe z nich kości" ("Gazeta Polska" 07.07.1903, 183, s. 2).

${ }^{35}$ Wnioskuję, że w cytowanym przez Jarosława Charkiewicza (2010b, s. 11) zdaniu autorstwa Iwana Popowa - „siła, moc ludzkiego ciała, zgodnie z powszechnym poglądem zawiera się właśnie w kościach, a nie w jego ciele" - słowo "ciała” zostało użyte na oznaczenie całego organizmu. 
odwołam się do Thomasa, który trafnie ujął ten problem: „(...) relikwie, nawet jako podpory ideologiczne, tracą na popularności w społeczeństwie, które dysponuje archiwami dla ustalenia swych początków, a lęk przed śmiercią topi w atrakcjach cywilizacji konsumpcyjnej i wierze w technokrację" (Thomas, 1991, s. 120). W Rosji najbardziej radykalny przejaw owej żądzy demaskacji miał miejsce niedługo po rewolucji październikowej, podczas przeprowadzonej przez bolszewików akcji otwierania relikwiarzy, rozpoczętej na początku marca 1919 roku, w ramach ogólnej kampanii mającej na celu ośmieszenie religii prawosławnej ${ }^{36}$. Znamienne, że operacja nie wywarła zamierzonego przez jej wykonawców wpływu na ludność chłopską. Richard Pipes przytacza opinię rosyjskiego chłopa, który twierdził, że „nasi święci znikli w niebie, a kiedy dowiedzieli się, że ich mogiły zostaną zbezczeszczone przez niewiernych, zamienili relikwie na szmaty i słomę. Był to wielki cud" (Pipes, 2005, s. 370).

\section{$* * *$}

W tekstach dotyczących XIX-wiecznych świętych starców rosyjskich ciało pojawia się w różnych kontekstach. Odgrywa istotną rolę w kreowaniu obrazu świętości starców za życia. Akceptowanie umiarkowanie natężonej choroby ciała umożliwia łatwiejsze osiąganie niezbędnego dla mnicha dystansu do ziemskiego życia. Potrzeba ciągłego odczuwania marności ludzkiej kondycji znajduje wyraz w praktykowanym przez starców umartwianiu ciała, obok mającej psychosomatyczne podłoże Modlitwy Jezusowej, jednym ze środków do uzyskania odczuwalnego zmysłami - dotyku, węchu, wzroku - stanu obecności Ducha Świętego.

W powieści Bracia Karamazow Fiodora Dostojewskiego ciało starca tuż po jego śmierci zostaje zdesakralizowane poprzez przypisanie wydzielanemu przez nie pośmiertnemu zapachowi znaczenia wyroku boskiego, negatywnie orzekającego o świętości zmarłego. Umożliwia to dyskredytację osoby starca za życia.

Na początku sierpnia 1903 roku, w obliczu nasilających się w Rosji niepokojów społecznych, odbyły się uroczystości kanonizacyjne św. starca Serafina z Sarowa, przeprowadzone z woli cara Mikołaja II oraz uświetnione jego obecnością. Relikwie św. Serafina, użyte

\footnotetext{
${ }^{36}$ W 1919 roku patriarcha Tichon próbując zapobiec otwarciu relikwiarza św. Sergiusza z Radoneża, powołał się na stanowisko biskupa Antoniego w sprawie relikwii św. Serafina z Sarowa przedstawione w artykule opublikowanym w 1903 roku w "Nowoje Wremia”. Tichon za Antonim przekonywał, że Cerkiew nie uważa nierozkładalności ciała za warunek świętości, dlatego też akcja otwierania relikwiarzy jest pozbawiona sensu (Freeze, 1996, s. 322, przyp. 56).
} 
w służbie władzy, podczas uroczystości kanonizacyjnych wystąpiły jako czynnik symbolicznie legitymizujący istniejący faktycznie mariaż tronu i ołtarza. Efekt został wzmocniony poprzez wspólną ucztę reprezentantów obu sfer, odbywającą się w pobliżu szczątków starca. Adorowane relikwie, w celu utrwalenia przywiązania ludu do dynastii panującej, zostały wykorzystane jako narzędzie komunikacji pomiędzy władcą a poddanymi, symbolizując propagowaną przez Mikołaja II ideę Świętej Rusi, zakładającą harmonię pomiędzy carem obrońcą prawosławia - a bogobojnym ludem. Powszechność poglądu utożsamiającego rozkład ciała z negacją świętości sprawiła, że szczątki św. Serafina w roku jego kanonizacji stały się przedmiotem sporu wznieconego przez zwalczający prawosławie petersburski związek, w celu skompromitowania Rosyjskiej Cerkwi Prawosławnej oraz cara Mikołaja Il jako inicjatora kanonizacji. Głos w tej sprawie zabrał metropolita Petersburga Antoni, wyjaśniając, że stopień rozkładu ciała nie jest decydującym kryterium świętości, a świętymi relikwiami mającymi uzdrawiającą moc są przede wszystkim kości zmarłego oraz związane z nim przedmioty. Relikwie mogą zatem zostać poddane sakralizacji (dzięki przypisaniu im cudownych funkcji leczniczych) bądź desakralizacji (poprzez zakwestionowanie ich nadzwyczajnego charakteru), w zależności od interesów manipulującej nimi grupy.

\section{Bibliografia}

Bachtin, M. (1970). Problemy poetyki Dostojewskiego. (N. Modzelewska, Tłum.). Warszawa: Państwowy Instytut Wydawniczy.

Bazylow, L. (1966). Polityka wewnętrzna caratu i ruchy spoleczne w Rosji na początku XX wieku. Warszawa: „Książka i Wiedza”.

Belyaeva, V. (b.d.). Śmierć w tradycji rosyjskiej - obrzędy cerkiewne, ludowe i socjalistyczne. etnologia.pl. Pobrano 16 marca 2017, z http://etnologia.pl/europa/teksty/smierc-w-tradycjirosyjskiej.php

Charkiewicz, J. (2010a). Kult świętych w prawosławiu. Elpis, 12(21-22), 109-159.

Charkiewicz, J. (2010b). Relikwie świętych w prawosławiu. Warszawa: Warszawska Metropolia Prawosławna.

Cieślik, I. (2012). Starcy Pustelni Optyńskiej. Kraków: TYNIEC Wydawnictwo Benedyktynów.

Detelić, M. (2010). St Paraskeve in the Balkan context. Folklore, 121(1), 94-105. https://doi. org/10.1080/00155870903482049

Dostojewski, F. (1984). Bracia Karamazow. (A. Wat, Tłum.). Warszawa: Państwowy Instytut Wydawniczy. 
Dostojewski, F. (1979). Listy. (Z. Podgórzec \& R. Przybylski, Tłum.). Warszawa: Państwowy Instytut Wydawniczy.

Eliade, M. (1974). Sacrum, mit, historia. (A. Tatarkiewicz, Tłum.). Warszawa: Państwowy Instytut Wydawniczy.

Figes, O. (2010). Taniec Nataszy: Z dziejów kultury rosyjskiej. (W. Jeżewski, Tłum.). Warszawa: Wydawnictwo "Magnum".

Freeze, G. L. (1996). Subversive piety: Religion and the Political Crisis in Late Imperial Russia. The Journal of Modern History, 68(2), 308-350. https://doi.org/10.1086/600768

Galiński, P. (1999). Wprowadzenie. W Opowieści pielgrzyma. Poznań: „W drodze”.

Kamiński, A. (2014). Starczestwo: Kierownictwo duchowe w Rosji w XIX wieku. Kraków: Fundacja LIST - Media dla Rodziny i Edukacji.

Kołogriwow, J. (2008). O świętym starcu Serafinie. W Św. Serafin z Sarowa, Ogień Ducha Świętego. (H. Paprocki, Tłum.). Kraków: Wydawnictwo Esprit.

Łeńska-Bąk, K. (2008). Ciało w poglądach Ojców Pustyni. W K. Łeńska-Bąk \& M. Sztandara (Red.), Doświadczane, opisywane, symboliczne: Ciało w dyskursach kulturowych (ss. 65-84). Opole: Wydawnictwo Uniwersytetu Opolskiego.

Nicholas, R. L. (1992). The Friends of God: Nicholas II and Alexandra at the canonization of Serafim of Sarov, July 1903. W C. Timberlake (Red.), Religious and secular forces in late tsarist Russia (ss. 206-221). Seattle: University of Washington Press.

Ochał, A. (1994). Rola Pustelni Optina w życiu i działalności wielkich pisarzy rosyjskich. W A. Kubiś \& M. Rusecki (Red.), Chrześcijańskie dziedzictwo bizantyńsko-słowiańskie (ss. 253-267). Lublin: Redakcja Wydawnictw Katolickiego Uniwersytetu Lubelskiego.

Opowieści pielgrzyma. (1999). (A. Wojnowski, Tłum.). Poznań: „W drodze”.

Pamiętnik Mikołaja II. (1990). (J. Kutta, Oprac.) (T. 2). Bydgoszcz: „Somix".

Pawełczyk-Dura, K. (2012). Kierunki i tendencje w XIX-wiecznej konserwatywnej myśli cerkiewnej w Rosji. Prace Naukowe Akademii im. Jana Długosza w Częstochowie. Filozofia, (9), 185-200.

Piekarska-Winkler, D. (2001). Sytuacja kościoła prawosławnego w Rosji XIX wieku a emocjonalno-afektywne nastawienie do ośrodków kultu i osób duchownych. Saeculum Christianum: Pismo historyczno-spoleczne, 8(2), 115-130.

Piekarska-Winkler, D. (2003). Renesans starcostwa. Ożywienie życia duchowego w Rosji XIX stulecia. Saeculum Christianum: Pismo historyczno-społeczne, 10(1), 123-133.

Pipes, R. (2005). Rosja bolszewików. (W. Jeżewski, Tłum.). Warszawa: „Magnum”.

Price, R. (2011). The canonization of Serafim of Sarov: Piety, prophecy and politics in late Imperial Russia. W P. Clarke \& T. Claydon (Red.), Saints and the sanctity (ss. 346-364). Woodbridge: Boydell \& Brewer.

Przybył, E. (2006). Prawosławie. Kraków: Wydawnictwo „Znak".

Sołowjew, S. M. (1962-1966). Istorija Rossii. t. I-XV. Moskwa.

Szkłowski, W. (1967). Lew Tołstoj. (R. Granas, Tłum.). Warszawa: Państwowy Instytut Wydawniczy. 
Święty Serafim Sarowski: Żywot i pouczenia. (1999). (H. Gabriel, M. Jakimiuk, \& J. Misiejuk, Red.). Hajnówka: Bratczyk.

Św. Serafin z Sarowa. (2008). Ogień Ducha Świętego. (H. Paprocki, Tłum.). Kraków: Wydawnictwo Esprit.

Thomas, L.-V. (1991). Trup: Od biologii do antropologii. (K. Kocjan, Tłum.). Łódź: Wydawnictwo Łódzkie.

Tołstoj, L. (1976). Listy. (M. Leśniewska, Tłum.) (T. 2, 1887-1910). Kraków: Wydawnictwo Literackie.

Uspienski, B., \& Żywow, W. M. (1992). Car i bóg: Semiotyczne aspekty sakralizacji monarchy w Rosji. (H. Paprocki, Tłum.). Warszawa: Państwowy Instytut Wydawniczy.

Witte, S. (1921). The memories of count Witte. (A. Yarmolinsky, Tłum.). Garden City, NY: Doubleday, Page \& Company.

Wodziński, C. (2009). Św. Idiota: Projekt antropologii apofatycznej. Gdańsk: Wydawnictwo Słowo/ Obraz Terytoria.

Ziolkowski, M. (1988). Hagiography and modern Russian literature. Princeton: Princeton University Press.

"Gazeta Handlowa" 03.08.1903. 174, s. 2.

„Gazeta Kaliska” 30.07.1903. 209, s. 3.

"Gazeta Polska” 07.07.1903. 183, s. 2.

"Gazeta Polska" 19.11.1903. 317, s. 3.

„Kurier Warszawski" 02.08.1903. 211, s. 7.

"Słowo" 01.08.1903. 174, s. 4.

"Słowo" 03.08.1903. 175, s. 3.

\section{Ciało i świętość. \\ Przypadek XIX-wiecznych świętych starców rosyjskich}

Artykuł rozważa odniesienia do ciała pojawiające się w wybranych tekstach dotyczących XIX-wiecznych rosyjskich świętych starców. Zostały w nim omówione trzy stany ciała świętego: za życia, tuż po śmierci oraz w postaci relikwii. Ciało odgrywa ważną rolę w kreowaniu obrazu świętości starców podczas ich życia. W rozdziale Odór trupi w powieści Bracia Karamazow Fiodora Dostojewskiego sakralny status martwego ciała starca Zosimy zostaje unieważniony przez zgromadzony tłum poprzez zinterpretowanie gnicia ciała jako wyroku bożego przeczącego świętości zmarłego. Dzięki temu możliwa jest dyskredytacja osoby starca za życia. Podobnie jak w powieści Dostojewskiego ciało zmarłego mnicha stało się przedmiotem sporu niedługo przed kanonizacją starca Serafina z Sarowa w 1903 roku. Powszechność poglądu utożsamiającego gnicie ciała z profanum sprawiła, że zwalczający prawosławie petersburski 
związek domagał się ponownego otwarcia trumny Serafina z Sarowa, chcąc podważyć wiarygodność Rosyjskiej Cerkwi Prawosławnej. Głos w sprawie szczątków starca zabrał metropolita Petersburga Antoni, przekonując, że nienaruszalność zwłok nie jest koniecznym warunkiem świętości. Podczas uroczystości kanonizacyjnych adorowane relikwie św. Serafina zostały wykorzystane w służbie władzy państwowej w celu wzmocnienia więzi pomiędzy carem Mikołajem II a ludem.

\section{Słowa kluczowe:}

Starczestwo; Pustelnia Optyńska; św. Serafin z Sarowa; starzec Zosima; Mikołaj II; relikwie; Fiodor Dostojewski; ciało

\section{The body and the sanctity. The case of the $19^{\text {th }}$-century Russian holy startsy}

The article considers references to the body appearing in selected texts concerning $19^{\text {th }}$ century Russian holy startsy. Three conditions of a holy man's body are discussed: living, immediately after death and as relics. The body plays an important role in creating the image of holiness of startsy during their lifetime. In the chapter The Breath of Corruption in Fyodor Dostoyevsky's Brothers Karamazov, the sacred status of starets Zosima's dead body is cancelled by the crowd's interpretation of his body's putrefaction as judgment of God refuting the holiness of the deceased monk. This, in turn, allows for a discrediting the life of the starets. Mirroring the events of Dostoyevsky's novel, the dead body of a monk became subject of dispute shortly before the canonization of the starets Seraphim of Sarov in 1903. Drawing on the commonness of the view identifying putrefaction of the body with profanity, a Petersburg anti-Orthodox association sought to discredit the Russian Orthodox Church by demanding that the coffin of Seraphim of Sarov is reopened. The answer of Antonius, the Metropolitan of Petersburg, was an article, in which he argued that inviolability of the body was not a necessary condition of holiness. During the canonization, the adored relics of Saint Seraphim were used by the state power to strengthen the bond between Tsar Nicholas II and the people.

\section{Keywords:}

Startsy; Optina Pustyn; St. Seraphim of Sarov; starets Zosima; Nicholas II; relics; Fyodor Dostoyevsky; body

\section{Citation:}

Grygiel, S. (2017). Ciało i świętość. Przypadek XIX-wiecznych świętych starców rosyjskich. Adeptus, 2017(9). https://doi.org/10.11649/a.1417 